Finanse, Rynki Finansowe, Ubezpieczenia nr 4/2018 (94), cz. 1

DOI: $10.18276 /$ frfu.2018.94/1-23

s. $267-273$

\title{
Measuring problems and performance assessing in the capital group
}

\author{
Edward Nowak ${ }^{*}$
}

\begin{abstract}
Purpose - The main aim of the article is to present the specificity and complexity of the measurement and assessment system of performance in a group, covering the parent and its subsidiaries.

Design/methodology/approach - The applied research methodology includes a critical analysis of literature in the field of management accounting, deductive and inductive reasoning, and logical reasoning.

Findings - The article specifies the main problems of measuring and assessing performance in groups, resulting from the complexity of economic groupings.

Originality/value - The arguments presented in the article have a theoretical character; however, the findings can be related to a practical application of discussed methods in the measurement and assessment of performance in groups.
\end{abstract}

Keywords: capital group, performance management, performance measurement, evaluation of performance, measures of performance

\section{Introduction}

Groups are usually complex economic organisations including the parent and its subsidiaries. They often have multi-level organisational structures. The complexity of groups is also expressed by the diverse nature of business activities of its entities. Sometimes they include units of a different legal form, i.e. commercial companies and state-owned enterprises. In the case of international groups, there are also political, cultural and other differences. The indicated factors make it difficult to carry out the measurement and assessment of performance in groups. In the case of such groupings of economic entities, multi-sided measurement and assessment of performance are always present. These activities should not only be used at the level of the whole group, but also by individual units (the parent and its subsidiaries). Additionally, connections between various entities within a group should be taken into account.

The subject of this article is dedicated to the measurement and assessment of performance in groups. Its main purpose is to show the specificity and complexity of the system for measuring and assessing the performance of a group as a whole and regarding the entities it

* prof. dr hab. Edward Nowak, Wroclaw University of Economics, Department of Cost Accounting, Managerial Accounting and Controlling, e-mail: edward.nowak@ue.wroc.pl. 
consists of. It is important to create an adequate system for measuring performance including measures that can be used in assessing performance of a different nature and scope. In order to achieve the goal and to verify the adopted thesis, literature studies were carried out, and deductive and inductive reasoning as well as logical reasoning were employed.

\section{Multifaceted and multidimensional aspects of measurement and assessment of performance in a group}

The performance of groups is a complex economic category, which includes various aspects of the activities of individual subsidiaries and the whole group. The multitude and variety of performance in such organisations means that various factors influence their formation. Therefore, the measurement of performance in groups is always multidimensional and the assessment of performance of individual units is usually multi-criteria.

In groups that are groupings of enterprises, the direct responsibility for results of the entire organisation is separated from the responsibility for performance in a parent and controlled entities. The complexity of the organisational structures of groups in which multilevel subordination between the units may occur requires the hierarchy of ordering different aspects of performance and their measures. In addition, appropriate methods for measuring different performance and appropriate methods of evaluation should be used.

Measurement of the performance of entities included in a group is the most important tool for assessing their activities. It enables the formalisation and objectivity of evaluation of performance at various levels of the organisational hierarchy of a group. It also creates conditions for indicating optimal business options, as the quantified objectives can be selection criteria for decision-making. An important decision problem in groups is the allocation of resources between subsidiaries. Expressing performance in the form of measures is the best way to assess the effectiveness of their use by individual units.

The system for measuring and assessing performance of subsidiaries in a group is built on the principle of cascading. The starting point is the level of strategic objectives of a group. These goals are attributed to the critical success factors of the entire group, which are assigned to key performance indicators. Next, the strategic objectives for individual subsidiaries are derived from the strategy of a group, which are a more detailed group goal. The goals of subsidiaries determine their critical success factors and key performance indicators, which are a refinement of these factors and measures related to the entire group (Lew, 2018).

The determination of the target values of the performance measures of subsidiaries is an important problem related to the assessment of performance in a group. These target values determine the expected states of accomplishments to be achieved by individual units. Target values of performance measures should motivate subsidiaries to take appropriate actions aimed at achieving them. The full involvement of the managerial staff and employees at various levels of the organisational hierarchy are of fundamental importance for the implementation of this postulate. The distance from the target values of performance measures is 
the basis for assessing the progress in achieving the objectives of a group entities (Nowak, 2011).

While building a system for measuring and evaluating performance in a group, it is necessary to ensure its internal cohesion (Nowak, 2018). The point is that it is possible to control not only the performance of individual subsidiaries, but also of a group as a whole. An important role in this system should be played by the parent company whose task is to set goals and monitor their implementation in dependent entities.

\section{Comparability of performance of group entities}

Measurement and evaluation of performance of entities belonging to a group are based on a set of accepted measures. It boils down to the processing of empirical data that mirror the shaping of these measures in individual units. Adequacy of the assessments depends to a large extent on the comparability of the data showing the status of performance. Comparability of performance is a set of conditions that should be met to ensure the correctness of the formulation of assessments and conclusions when comparing their status (Nowak, 2017, p. 47).

Comparability of data which numerically describe the performance is disturbed by changes occurring in groups. Taking into account the reasons for the distortions of this comparability, the following types can be distinguished: subjectivity, objectivity, methodology, time and price. The first three types of comparability have the most important meanings for comparative analyses of performance of group entities.

Subject comparability means that a group consists of identical subsidiaries. In the case of dynamic analysis of performance, it is assumed that there are no organisational changes in time, such as division and merger, transfer and taking over or liquidation of subsidiaries. When it comes to cross-section comparative analysis, it is possible to compare subsidiaries engaging in the same type of activity. The point here is to compare entities that belong to the same category of responsibility (e.g. investment centres).

The cross-subject comparative analysis of performance in a group is disturbed by the various organisational transformations taking place in it. Striving to improve the effectiveness of achieving the objectives and increase the efficiency of operations contribute to changes in the configuration of groups. The need to adapt to changes taking place in their external environment is also the reason for frequent reorganisations in the structure of such groupings of enterprises (Sikacz, 2011, pp. 120-121).

Object comparability in a group means a dynamic and cross-sectional material compatibility of the range of economic phenomena subject to measurement and assessment. This type of comparability of subsidiaries refers to performance of a specific nature of the company's activities. The subject of comparisons can therefore be the only performance of the same nature, regarding similar phenomena and economic processes.

Methodological comparability in a group is based on applying identical concepts and the same principles of internal classification of performance in entities belonging to a group. 
It also means using the same set of completion measures in the compared subsidiaries. It is also important to achieve the commensurability of the various performance compared with one another.

Comparability of subsidiaries included in a given group is never absolute. It is difficult to achieve complete comparability due to the performance. Subsidiaries belonging to a specific group are always characterised by a smaller or larger specificity. Their performance are influenced not only by internal factors but also by external ones. Therefore, a compromise should be sought between the comparability of performance of subsidiaries and their specificity. The point is to highlight the factors that are crucial for this specificity, determining the results of the activities of individual entities and the entire group.

The next two sections of the article will present the possibilities of using two selected instruments to assess the achievements of the group's units: a balanced scorecard and benchmarking. These instruments can be used in a comparative analysis of the units included in the studied group.

\section{A balanced scorecard in a group}

One of the more well-known systems for measuring and evaluating performance in business organisations is a balanced scorecard, developed by R.S. Kaplan and D.P. Norton (2006). This card enables multidimensional measurement of performance that has been grouped into four perspectives: financial, customer, internal processes, and learning and growth. In a balanced scorecard measures of a different nature are compared: financial and nonfinancial, anticipating and delaying, regarding "hard" and "soft" areas (Kowalewski, 2016). The general (strategic) and detailed objectives as well as measures to achieve these goals are defined for each business perspective. At the same time, there are indicated actions to be undertaken to achieve individual objectives.

A balanced scorecard, after appropriate adjustments, can be used to measure and evaluate performance in a group. In this case, this system will include the main scorecard of the entire group and individual scorecards of individual entities included in it. These individual scorecards are developed on the principle of cascading the main scorecard, which involves a gradual conversion into the lower organisational levels of the group. Because groups may have multi-level relationships between individuals, therefore cascading of the group scorecard takes place sequentially: first to the higher-level parent units, through the lower-level parent units to the subsidiaries.

The performance measurement and assessment system in a group should include the group strategy map and a scorecard for the entire group and its entities. Moreover, for each perspective, it is necessary to define the strategic objectives resulting from it, performance measures, target values of these measures as well as initiatives and actions aimed at effective achievement of goals. At the same time, within each individual scorecard there should be indicated links of specific perspectives with strategic objectives and key success factors 
correlated with them. In the case of using a balanced scorecard in a group, it is important to coordinate the activities of all units included in the group: parent units at the given level and subsidiaries. Moreover, a strategic adjustment should be made in the entire group (Kowalewski, 2018). This adjustment can take place sequentially, starting from the head office level, through lower hierarchical levels. Sometimes, however, it begins with lower or higher-level parent units, until a group strategy map is reached.

\section{Benchmarking performance in a group}

In a group the results of the better-performing units can be obscured by worse performance of other units. Therefore, the assessment of performance in a group is relative, i.e. that a comparative analysis of the performance of individual entities included in the group should be carried out. The modern approach used in such analysis is benchmarking, which can be not only external but also internal.

This article will talk about internal benchmarking, carried out within a group. The subject of this group-internal benchmarking will be the performance of individual subsidiaries. Conducting this kind of benchmarking requires that individual performance under evaluation should be expressed using appropriate measures. Therefore, the starting point for conducting benchmarking in a group is measuring the performance of the entities included in the group.

Benchmarking performance in a group is a tool used to compare the performance of dependent entities and to detect factors that determine the advantage of certain units over others. Managers should know which units operate the most efficiently and effectively. They should also have an orientation in the state of accomplishments in other units compared to the reference ones. Benchmarking allows to answer the question what it means to be the best in a group and what should be done to achieve this state (Mikel, Schroeder, 2001, p. 70).

When applying benchmarking to the assessment of performance in a group, equal units should be treated as responsibility centres for specific results of operations. Therefore, intra-group benchmarking should take into account the levels of authority and liability of subsidiaries. As a result it is possible to compare only subsidiaries that have similar rights and responsibilities (e.g., performance centres with each other, investment centres among themselves). It is also important that the performance of individual subsidiaries is assessed and compared on the basis of the size of the centres of responsibility controlled by managers who influence them (Bogan, English, 2006, p.77).

Intra-group performance benchmarking is quantitative, which is why it is carried out using a standard set of performance measures for a given class of dependent entities treated as responsibility centres. As a part of this benchmarking, it is possible to compare the performance of individual units with the performance of the best unit. Therefore, the benchmarking of performance is a formalised method of managing performance in a group, which is undoubtedly its important advantage. Its main goal is to improve the efficiency of operations and the effectiveness of achieving targets by subsidiaries belonging to a group. 
The goals of benchmarking performance are achieved by improving processes and products performed in subsidiaries. At the same time, such a targeted intra-group benchmarking is not a one-off or a periodic undertaking. It is assumed to be a continuous process, including activities undertaken systematically in all units included in the group (Mikel, Schroeder, 2001, p. 75). Comparisons in groups should be an inseparable element of the knowledge management system in these economic organisations (Szydełko, 2018).

\section{Conclusions}

This article certainly does not exhaust the problem of measurement and assessment of performance in groups. It indicates only the most important problems specific to this area of management of performance in such groupings of enterprises in comparison with separate economic units. However, selected issues were basically indicated without discussing specific issues related to them. This is mainly due to restrictions on the volume of the article and the desire to synthetically present fundamental problems.

Measurement and evaluation of performance in groups are complex but at the same time interesting matters. So far, management accounting has not developed solutions in this field that could be considered satisfactory. At the same time, in the global economy, there are more and more economic groups having the character of groups with extensive organisational structures. Therefore, the issue of performance management in groups is still valid and constitutes a noticeable gap in the literature in the field of management accounting.

It is impossible to create one universal system for measuring and evaluating performance in groups, which could be used in any organisation of this type. This is mainly due to the very large diversity of groups in terms of the scope of activity, legal and organisational form, connections between groups of units, ownership forms, range of activity (Sikacz, 2011, pp. 36-37). Therefore, the proposals presented in this article should be treated as guidelines for developing specific solutions for the studied group with a certain specificity.

\section{References}

Bogan, Ch.E., English, M.J. (2006). Benchmarking jako klucz do najlepszych praktyk. Gliwice: Helion.

Kaplan, R.S., Norton, D.P. (2006). Strategiczna karta wyników. Jak przelożyć strategię na działania. Warsaw: Wydawnictwo Naukowe PWN.

Kowalewski, M. (2016). Pomiar dokonań przedsiębiorstwa. In: Zarządzanie dokonaniami w organizacjach, ed. E. Nowak. Warsaw: PWE.

Kowalewski, M. (2018). Zarządzanie dokonaniami w grupach kapitałowych. In: Rachunkowość zarzadcza w grupach kapitatowych, ed. E. Nowak. Warsaw: CeDeWu.

Lew, G. (2018). Ośrodki odpowiedzialności grupy kapitałowej. Rachunkowość zarzadcza w grupach kapitałowych, ed. E. Nowak. Warsaw: CeDeWu.

Mikel, H., Schroeder, R. (2001). Six sigma. Wykorzystanie programu jakości do poprawy wyników finansowych. Cracow: Oficyna Ekonomiczna. 
Nowak, E. (2017). Analiza sprawozdań finansowych. Warsaw: PWE.

Nowak, E. (2018). Grupa kapitałowa jako podmiot rachunkowości zarządczej. In: Rachunkowość zarządcza w grupach kapitatowych, ed. E. Nowak. Warsaw: CeDeWu.

Nowak, E. (2011). Wielowymiarowość systemu oceny dokonań przedsiębiorstwa. "Prace Naukowe Uniwersytetu Ekonomicznego we Wrocławiu", 182.

Sikacz, H. (2011). Ocena sytuacji finansowej operacyjnych grup kapitalowych. Warsaw: Wolters Kluwer Polska. Szydełko, M. (2018). Benchmarking w grupach kapitałowych. In: Rachunkowość zarzadcza w grupach kapitatowych, ed. E. Nowak. Warsaw: CeDeWu.

\section{PROBLEMY POMIARU I OCENY DOKONAŃ W GRUPIE KAPITALOWEJ}

Streszczenie: $\mathrm{Cel}$ - Głównym celem artykułu jest ukazanie specyfiki i złożoności systemu pomiaru i oceny dokonań w grupie kapitałowej, obejmującego całą grupę oraz jednostki zależne wchodzące w skład grupy.

Metodologia badania - Zastosowana metodyka badań obejmuje krytyczną analizę literatury z zakresu rachunkowości zarządczej, metody dedukcji i indukcji oraz wnioskowania logicznego.

Wynik - W artykule wyspecyfikowano główne problemy przeprowadzania pomiaru i oceny dokonań w grupach kapitałowych wynikające ze złożoności ugrupowań gospodarczych.

Oryginalność/wartość - Wywody zaprezentowane w artykule mają teoretyczny charakter, jednakże poczynione ustalenia mogą być odniesione do praktycznego zastosowania omawianych metod w pomiarze i ocenie dokonań w grupach kapitałowych.

Słowa kluczowe: grupa kapitałowa, zarządzanie dokonaniami, pomiar dokonań, ocena dokonań, mierniki dokonań

\section{Citation}

Nowak, E. (2018). Measuring problems and performance assessing in the capital group. Finanse, Rynki Finansowe, Ubezpieczenia, 4 (94/1), 267-273. DOI: 10.18276/frfu.2018.94/1-23. 